\title{
The contrasting biology of tropical versus temperate Nothofagus species and its relevance to interpretations of Cenozoic rainforest history in southeast Australia
}

\author{
Jennifer Read \\ School of Biological Sciences, Monash University, Victoria, Australia \\ jenny.read@sci.monash.edu.au
}

\section{Robert S. Hill}

Faculty of Sciences, University of Adelaide, South Australia

South Australian Museum, Adelaide, South Australia

\section{Geoffrey S. Hope}

Department of Archaeology and Natural History, Research School of Pacific and Asian Studies, Australian National University, Canberra, Australia

\section{Raymond J. Carpenter}

Faculty of Sciences, University of Adelaide, South Australia

\section{Introduction}

Given the uncertain impacts of global climate change, it is becoming increasingly important to understand the factors controlling vegetation change, species distributions and vagility. The fossil record provides the only real source of long-term data for changes in distributions and characteristics of species and vegetation types. However, while making an enormous contribution to our knowledge of vegetation history, interpretation is limited by the incomplete fossil record, understanding of the biology of fossil species, and insufficient precision regarding the timing of key environmental events.

One advantage of the macrofossil record, particularly that relating to leaves, is that better indications can be obtained about the biology of fossil species than from microfossils alone, allowing clearer insights into possible controls of vegetation change in the distant 
past. For example, trends in leaf shape, size, margins, texture and anatomical features such as stomatal density have been described or modelled in relation to a range of environmental factors (Givnish 1979; Beerling and Kelly 1996; McElwain and Chaloner 1996; Wilf et al. 1998; Beerling et al. 2002; Royer and Wilf 2006). Some leaf traits also allow the systematic affinities of leaf fossils to be determined with greater rigour than for most microfossils. Nearest Living Relative (NLR) analysis is the most compelling approach to the reconstruction of past environments from botanical evidence, especially for the time since angiosperms assumed dominance (Hill and Scriven 1997). However, this approach relies on a detailed understanding of the biology of living relatives, for which data are often lacking. Here, we use studies of extant Nothofagus (Nothofagaceae) species to explore effects of changing climate on the distribution of evergreen Nothofagus during the Cenozoic in southeast Australia, focusing on the Palaeocene to Pliocene as a case study to explore effects of climate change on rainforest. We focus in particular on the changing composition of the rainforest, rather than on its extent.

\section{Nothofagus - key genus in time and space ${ }^{1}$}

Nothofagus is a key genus in the fossil record of the Southern Hemisphere, represented through an $80 \mathrm{Myr}$ record across much of Gondwana (southern South America, Antarctica, New Zealand and Australia) in the form of pollen, leaves and reproductive organs (Hill and Dettmann 1996; Hill 2001). This evidence, together with the broad geographic range of living species, provides the opportunity of interpreting the distribution and ecology of different Nothofagus taxa in response to environmental changes over time. Nothofagus is now most often found in rainforests, but some deciduous species extend into mediterranean climates in central Chile (Donoso 1996) and into cool, dry climates of the eastern Andes (Veblen et al. 1996). Within rainforests, habitats range from equatorial montane forests in New Guinea (here taken to comprise the West Papuan region of Indonesia and Papua New Guinea), to the cold southernmost forests of Tierra del Fuego, with deciduous species extending to the treeline in Tasmania and southern South America. Nothofagus even occurs across a wide range of soils, including relatively fertile soils, as well as old, leached, nutrient-poor (e.g. Read and Brown 1996) and ultramafic soils (Read and Hope 1996). Moreover, the pollen and often the macrofossils of Nothofagus allow distinction between tropical and temperate taxa, and among some temperate taxa (Hill 1991; Hill and Read 1991), although some caution is necessary in interpreting fossils as belonging to extant clades (Jordan and Hill 1999; Sauquet et al. 2009). Species typically show relatively localised seed dispersal, with most seed-fall occurring close to parent trees (e.g. Ogden et al. 1996), but long-distance dispersal does seem to occur (e.g. Ogden et al. 1996) and may have contributed significantly to migration in the past (Hill and Dettmann 1996). A better knowledge of the biology of these species and the factors limiting their distribution should allow better interpretation of the fossil record, and hence of factors limiting tree distributions and vagility.

The fossil record of Nothofagus is unquestionably one of the best of any plant group worldwide. However, one problem with using Nothofagus as a case study of species distribution and diversity through time is that the genus is apparently well past its time of maximum diversity (Hill 2001). This means that extant species might not represent the full range of ecological responses that Nothofagus has exhibited throughout its history. Hence, it may be difficult to fully reconstruct the environmental changes to which members of this genus have responded in the past. Furthermore, this approach rests on the assumption that key features of the biology of fossil species that have influenced their distribution have been retained, at least in part, in living relatives (discussed in Read et al. 1990a). Leaves of some fossil 
Nothofagus species are morphologically very similar to those of living species (Hill 2001), suggesting that aspects of their biology have been conserved to some degree. In addition, some Nothofagus taxa that once coexisted diverged greatly in their distribution after the early Miocene, suggesting there was already ecophysiological differentiation in place. Nevertheless, caution must be applied in use of this approach.

\section{Historical changes in climate and vegetation responses, focusing on Nothofagus}

The first pollen grains attributed to Nothofagus appear at very high latitudes at about $80 \mathrm{Ma}$ (Hill and Dettmann 1996). We know little about the palaeoecology of these early species in part because the records are predominantly from microfossils and confidence in the NLR approach decreases with the age of the fossils. Nothofagus species were present in the region through the cooling of the late Cretaceous, and during the mild, wet Palaeocene (with periods of winter darkness at high latitudes) (Truswell 1993; McGowran et al. 2000). During the non-seasonal/megathermal early Eocene, Nothofagus may have been common only in the Tasmanian highlands, becoming more widespread across Australia during the middle to late Eocene when conditions were cooler (mesothermal) with little or no seasonal variation (McGowran et al. 2000). Some assemblages recorded at that time, such as suggested deciduous Nothofagus species in diverse angiosperm forests in the middle Eocene (Scriven et al. 1995), have no modern analogues.

The development of what appear to be modern climatic responses in the genus begins with its rise to dominance at high southern latitudes from about the late Eocene $(\sim 40$ $\mathrm{Ma}$ ) onwards (Hill 2001). This was more or less coincident with the end of the early Palaeogene 'Greenhouse' interval of global warmth, high atmospheric $\mathrm{CO}_{2}$ levels (Pagani et al. 2005) and high water availability, and the initiation of the major Cenozoic cooling trend, as Australia, and later South America, separated from Antarctica, resulting in the development of the circum-Antarctic ocean current. Nothofagus then assumed dominance over much of Australia, Antarctica, southern South America and New Zealand, probably reaching its greatest diversity and widest distribution during the Oligocene (Hill 2001). Some extraordinary coexistence of Nothofagus taxa occurred at this time, most notably at Little Rapid River in northwest Tasmania, where several species from three of the four extant subgenera (Brassospora, Nothofagus and Lophozonia), and possibly even the remaining subgenus (Fuscospora), coexisted within a small catchment area (Hill 1991, 1994, 2001). Today, subgenus Brassospora occurs only in New Guinea and New Caledonia, subgenus Nothofagus occurs only in southern South America, and the other subgenera occur in each of Australia, New Zealand and South America (Hill and Dettmann 1996). Given the considerable latitudinal and longitudinal separation of some subgenera today, their coexistence at any time in the past is remarkable. This poses two related questions that we will focus on here: What conditions allowed these subgenera to coexist in the past? And, in particular, which environmental changes forced the wide separation of some subgenera today? The most obvious environmental changes to explore are as follows: photoperiod regime and sunlight angle; atmospheric $\mathrm{CO}_{2}$ levels; water availability, seasonality of rainfall and drought frequency; mean annual temperature, seasonality of temperature and temperature extremes (both high and low); and disturbance regimes, including fire. This paper does not focus on disturbance, but, for example, increased charcoal levels from the middle Miocene in southeast Australia are indicative of increased burning, which must have affected rainforest composition and distribution (Kershaw et al. 2002). 


\section{The differing biology of tropical vs temperate Nothofagus species}

There are relatively few data that allow clear interpretations of evolved physiological traits associated with latitudinal position. To avoid confounding influences of contrasting growth conditions eliciting plastic responses, the plants must be grown in common conditions, usually requiring study of seedlings in pot trials. Even the simplest comparisons can sometimes indicate susceptibilities of genotypes to particular conditions, which may at least allow hypotheses to be refined, and at best signal key traits (Grime 1965). Unfortunately, mature plants, including reproductive traits, cannot easily be examined in this way in slowgrowing trees such as Nothofagus. Field-based studies provide valuable adjuncts in this regard. Here, we review data that may be informative for interpreting past changes in distribution and abundance of evergreen Nothofagus taxa, focusing on the comparative biology of species from Australia and New Guinea, for which we have most information.

\section{Current distributions and climate range}

Nothofagus has a wide latitudinal distribution through the Australasian region, from northwest New Guinea to southeast New Caledonia, and from southeast Queensland along the eastern highlands to southernmost Tasmania and New Zealand (i.e. c. $0-46^{\circ} \mathrm{S}$ ). The tropical group (subgenus Brassospora) of 19 species is confined to New Guinea (14 species, c. 600-3100 m asl) and New Caledonia (five species, $160-1350 \mathrm{~m}$ asl). Just three Nothofagus species occur in Australia, the evergreen species $N$. moorei in the eastern highlands of mid-NSW to southeast Queensland (c. 500-1550 m asl) and N. cunninghamii in Victoria and Tasmania (0-1450 m asl) (subgenus Lophozonia), and Australia's only winter (cold) deciduous species, N. gunnii (subgenus Fuscospora), restricted to the Tasmanian highlands (550-1500 m asl). The main climate differences between the tropical and temperate species relate to winter minimum temperatures, seasonality of temperature, summer precipitation and precipitation of the wettest period (Table 1, Figure 1). The Australian species separate along a gradient influenced most strongly by temperature of the warmest month, temperature of the wettest period, and winter rainfall (Table 1, Figure 1). In particular, $N$. moorei experiences high rainfall through the warmest time of the year. The New Guinea species experience little seasonal variation in temperature, and although rainfall is seasonal, monthly rainfall is usually high even in the 'dry' season (Table 1). Hence, these species effectively experience an ever-wet climate (New Caledonian species experience a more seasonal climate that includes a short, warm dry season: Read et al. 2005). In contrast, for $N$. cunninghamii, the warmest time of the year is on average the driest (Table 1).

\section{Comparative responses of tropical vs temperate Nothofagus species to light regimes}

Variation in rainfall regime and cloudiness, together with latitudinal position, influence the light regimes experienced by Nothofagus species. Two components of light regimes are relevant in this context: irradiance and photoperiod. The limited data available suggest that the Australian evergreen species have higher light requirements than some of the New Guinea species, as judged by slightly higher light compensation points, dark respiration rates and light saturation points (Figure 2). However, the tropical species are quite variable: $N$. resinosa shows similar photosynthetic light-response curves to those of the temperate species, but some tropical species appear to be a little more shade-tolerant (Figure 2). Other factors such as biomass allocation patterns will also influence whole-plant shade tolerance. Shade tolerance can influence population dynamics and the degree of dependence on exogenous disturbance (e.g. Read et al. 1990b). It is likely that Palaeogene forests in southeast Australia had a high leaf area index (total leaf area per unit ground area), higher than in the current Nothofagus forests of southeast Australia, given the suggested high year-round rainfall and warm to mild 
Table 1. Climate variables derived by BIOCLIM (Nix 1986) for evergreen Nothofagus species from New Guinea (all species combined) and Australia. Temperature variables $\left({ }^{\circ} \mathrm{C}\right)$ and precipitation $(\mathrm{mm})$ are given as mean \pm standard deviation $(5-95$ percentile in brackets) for $n$ location records. The data for New Guinea species are updated from Read et al. (2005). The data for Australian species are updated from Read et al. (2010). Seasonal temperature range is calculated as the hottest-month mean temperature minus the coldest-month mean temperature. Precipitation seasonality is calculated as the coefficient of variation across monthly values

\begin{tabular}{|c|c|c|c|}
\hline Climate variable & $\begin{array}{c}\text { New Guinea species } \\
\quad(n=301)\end{array}$ & $\begin{array}{l}\text { N. moorei } \\
(n=139)\end{array}$ & $\begin{array}{l}\text { N. cunninghamii } \\
\quad(n=318)\end{array}$ \\
\hline Annual mean temperature & $\begin{array}{c}16.1 \pm 2.9 \\
(12.0-21.5)\end{array}$ & $\begin{array}{c}12.2 \pm 1.4 \\
(10.1-14.6)\end{array}$ & $\begin{array}{c}9.5 \pm 2.0 \\
(5.8-12.4)\end{array}$ \\
\hline Hottest-month mean temp. & $\begin{array}{c}16.6 \pm 3.0 \\
(12.5-22.1)\end{array}$ & $\begin{array}{c}17.5 \pm 1.6 \\
(15.3-19.9) \\
\end{array}$ & $\begin{array}{c}15.1 \pm 2.3 \\
(11.0-18.4) \\
\end{array}$ \\
\hline Coldest-month mean temp. & $\begin{array}{c}15.3 \pm 2.8 \\
(11.2-20.2)\end{array}$ & $\begin{array}{l}5.2 \pm 2.1 \\
(2.6-9.1)\end{array}$ & $\begin{array}{l}4.8 \pm 2.1 \\
(1.2-7.8)\end{array}$ \\
\hline Hottest-month max. temp. & $\begin{array}{c}21.4 \pm 3.1 \\
(16.5-27.2)\end{array}$ & $\begin{array}{l}23.2 \pm 1.4 \\
(21.0-25.7)\end{array}$ & $\begin{array}{c}20.8 \pm 2.8 \\
(15.9-25.3)\end{array}$ \\
\hline Coldest-month min. temp. & $\begin{array}{l}10.7 \pm 3.0 \\
(6.9-16.4)\end{array}$ & $\begin{array}{c}0.9 \pm 1.6 \\
(-0.9-5.1)\end{array}$ & $\begin{array}{l}1.6 \pm 1.8 \\
(-1.5-4.2)\end{array}$ \\
\hline Diurnal temperature range & $\begin{array}{l}10.4 \pm 1.6 \\
(7.1-12.1)\end{array}$ & $\begin{array}{l}11.1 \pm 1.1 \\
(8.1-12.5)\end{array}$ & $\begin{array}{c}11.9 \pm 1.5 \\
(10.0-14.6)\end{array}$ \\
\hline Seasonal temperature range & $\begin{array}{l}1.3 \pm 0.8 \\
(0.8-1.9)\end{array}$ & $\begin{array}{c}12.4 \pm 0.8 \\
(10.8-13.4)\end{array}$ & $\begin{array}{l}10.3 \pm 1.6 \\
(7.9-12.8)\end{array}$ \\
\hline Annual precipitation & $\begin{array}{l}2891 \pm 743 \\
(2073-4439)\end{array}$ & $\begin{array}{l}1633 \pm 325 \\
(1229-2282)\end{array}$ & $\begin{array}{c}1816 \pm 523 \\
(1127-2950)\end{array}$ \\
\hline Precipitation of hottest quarter & $\begin{array}{c}888 \pm 249 \\
(666-1159) \\
\end{array}$ & $\begin{array}{l}564 \pm 142 \\
(390-844)\end{array}$ & $\begin{array}{c}304 \pm 92 \\
(191-516) \\
\end{array}$ \\
\hline Precipitation of coldest quarter & $\begin{array}{c}526 \pm 254 \\
(301-1069)\end{array}$ & $\begin{array}{c}315 \pm 49 \\
(232-388)\end{array}$ & $\begin{array}{l}551 \pm 158 \\
(351-887) \\
\end{array}$ \\
\hline Precipitation of wettest quarter & $\begin{array}{c}955 \pm 348 \\
(689-1491)\end{array}$ & $\begin{array}{l}611 \pm 179 \\
(396-959) \\
\end{array}$ & $\begin{array}{l}570 \pm 160 \\
(364-899)\end{array}$ \\
\hline Precipitation of driest quarter & $\begin{array}{l}474 \pm 166 \\
(301-869) \\
\end{array}$ & $\begin{array}{c}249 \pm 35 \\
(194-302)\end{array}$ & $\begin{array}{c}304 \pm 95 \\
(191-516)\end{array}$ \\
\hline Precipitation seasonality & $\begin{array}{l}28 \pm 11 \\
(14-44)\end{array}$ & $\begin{array}{l}34 \pm 11 \\
(18-46)\end{array}$ & $\begin{array}{l}25 \pm 5 \\
(18-35)\end{array}$ \\
\hline
\end{tabular}

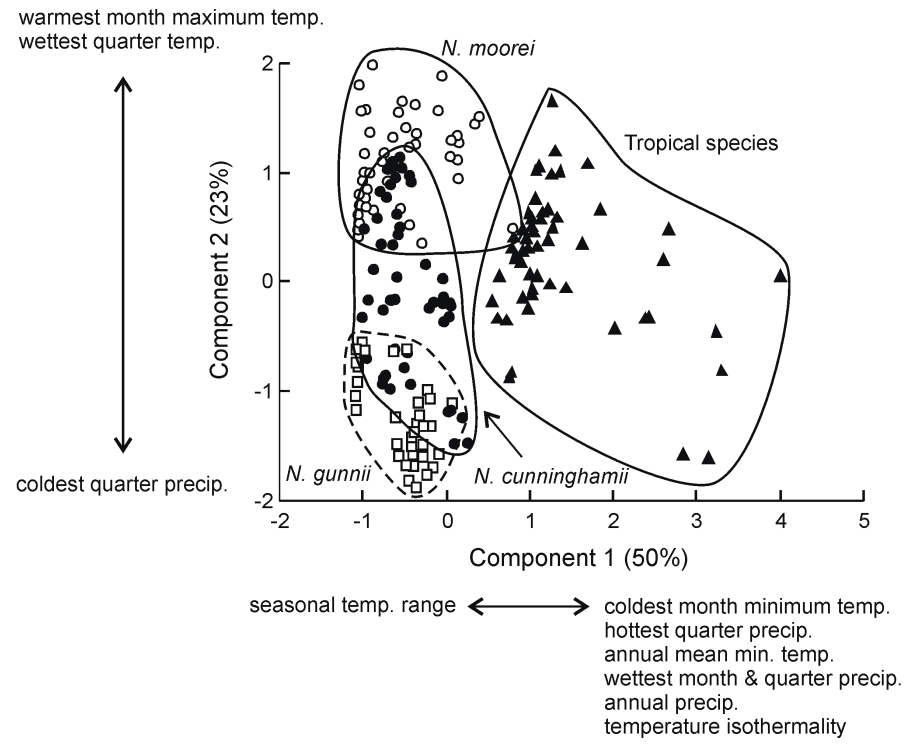

Figure 1. Ordination (PCA) of site climate variables for Nothofagus species from New Guinea and Australia. A subset of c. 50 locations was selected randomly for each Australian species and for the New Guinea species as a whole, to avoid bias towards well-surveyed species. The percentage contribution of the first two components to the total variation is indicated, and the variables contributing most strongly to each axis (component loadings $\geq 0.80$ ) are listed. Climate data are from Read et al. (2005) and Read and Brown (1996), using 20 of the 24 BIOCLIM-derived variables (excluding some temperature variables) 
temperatures. If so, opportunities for regeneration of some shade-intolerant species may have been relatively limited, possibly associated with exogenous disturbance, as found in many Nothofagus species in both tropical (Read and Hope 1996) and temperate (Ogden et al. 1996; Veblen et al. 1996) regions today. Under these conditions, some Nothofagus species may have been confined to disturbance-prone sites, such as ridge tops, or to suboptimal sites.

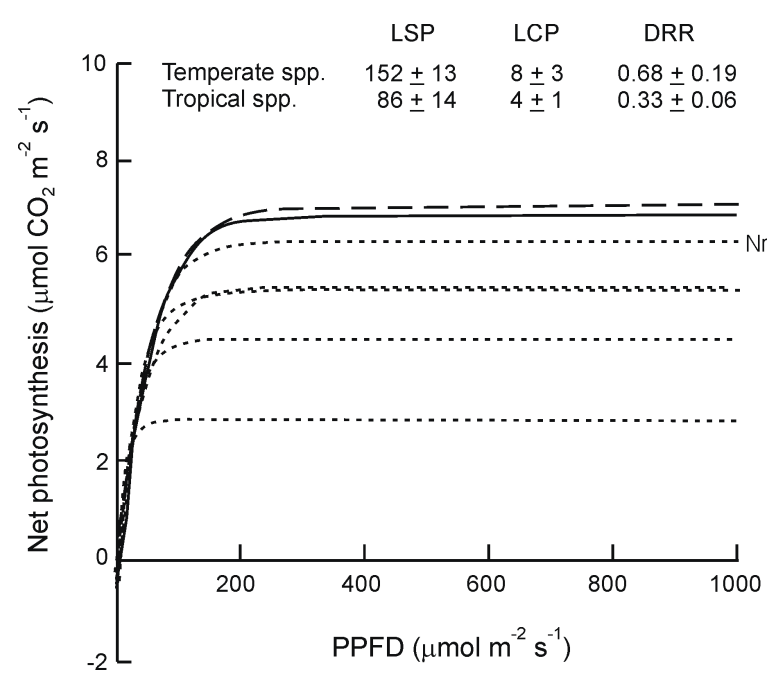

Figure 2. Instantaneous light-dependence curves of net photosynthesis of shade-grown evergreen Nothofagus species from New Guinea and Australia. Nothofagus cunninghamii is shown by a solid line, $N$. moorei by long dashes, and tropical species (N. pullei, N. resinosa (Nr), $N$. crenata var. sapei, N. grandis and N. brassii) by short dashes. Plants were grown at a photosynthetic photon flux

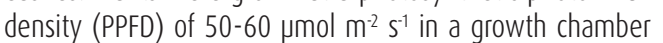
at $20^{\circ} \mathrm{C}$ with $12 \mathrm{~h}$ days. The average dark respiration rate (DRR, umol $\mathrm{CO}_{2} \mathrm{~m}^{-2} \mathrm{~s}^{-1}$ ), light compensation point (LCP, $\mu \mathrm{mol}$ $\mathrm{m}^{-2} \mathrm{~s}^{-1}$ ) and light saturation point (LSP $\mu \mathrm{mol} \mathrm{m}^{-2} \mathrm{~s}^{-1}$ ) are given for tropical ( $n=5$ species) and temperate $(n=2)$ species

\section{Nothofagus at high latitudes - the constraints of polar winters}

Nothofagus has a long history at high latitudes. It currently extends south to c. $56^{\circ}$ on the islands of Cape Horn, but during the late Cretaceous and early Palaeogene, occurred even further south in the Antarctic region (Hill 2001). Exchange of many taxa between Australia and South America, including Nothofagus, is likely to have occurred across latitudes of at least $80^{\circ}$ $S$ during this time. Today, high-latitude forests experience severe conditions - extremely low minimum temperatures, short and cool growing seasons and low availability of soil nutrients and water - with growth and survival potentially limited by factors including frost damage, physiological drought and carbon balance (Woodward 1987; Givnish 2002). However, a range of evidence, including plant fossils, suggests that milder temperatures prevailed at southern high latitudes during the Cretaceous and Palaeogene. Cool winters, rather than severe freezing conditions, occurred along the coastal margins of Antarctica (Otto-Bliesner and Upchurch 1997; Hayes et al. 2006; Poole and Cantrill 2006), and there was even an abundance of now mostly tropical taxa (e.g. cycads, $N y p a$, Lauraceae) at a coastal early Eocene site in Tasmania estimated to have been at 65\% S (Pole and Macphail 1996; Carpenter et al. 2007).

While milder winters may have allowed species without highly developed cold-adaptation to occupy polar forests, the dark and mild winters may have constrained tree growth and survival (by primary means or via competition) through negative effects on carbon balance. In addition, the low angle of light may have reduced rates of carbon assimilation during summer, particularly for species of the understorey and lower canopy (Specht et al. 1992). No modern analogue exists for these high-latitude environments, especially given the likely high atmospheric $\mathrm{CO}_{2}$ concentrations, but interacting effects of temperature and light regime on modern vegetation limits and species mixtures have been reported at high latitudes in Scotland and Ireland (Bannister 1976). The typically thin leaves of deciduous plants often do not fossilise well, but there is abundant evidence that deciduous taxa were common in some parts of southern Australia during the Palaeogene (Hill 2001). The deciduous habit may have been advantageous for canopy species at high latitudes (e.g. Axelrod 1984; Spicer 1987), for example in terms of carbon balance, although the role of the latter has been questioned (Royer et al. 2003). It is anyway likely that these unusual high-latitude conditions acted as a sieve to 
species movements between and within land masses during the Cretaceous and Palaeogene (Read and Francis 1992). They may also have contributed to the sometimes greater than expected abundance of gymnosperms and Nothofagus in mild-to-warm climates and to the abundance of deciduous species at this time in southeast Australia, where only one winterdeciduous species occurs today.

\section{Responses to freezing temperatures}

As temperatures decreased and seasonality increased during the middle Miocene-Pliocene in southeast Australia, plants would have been exposed to lower minimum temperatures, with temperatures continuing to decline into the Pleistocene. In addition, the drying climate with increasingly seasonal rainfall may have led to a higher incidence of frosts as the cooler season became drier. There is certainly some correspondence of changes in species distribution with the levels of foliar frost resistance recorded in extant relatives: tropical Nothofagus species have a lower frost resistance than southern evergreen species (Figure 3), and Tasmanian rainforest species of several other genera are typically more frost resistant than related species native to NSW and Queensland (Read and Hill 1989). However, the frost resistance of New Guinea Nothofagus species native to cool climates is close to that of $N$. moorei, despite the estimated higher (by $8-11^{\circ} \mathrm{C}$ ) mean minimum temperature of the coldest month (MTCM) experienced by the tropical species (Read and Hope 1989, 1996) (Figure 3). This comparison suggests there is no fundamental difference in capacity to develop frost resistance between the New Guinea species and N. moorei, i.e. the genetic difference is potentially small.

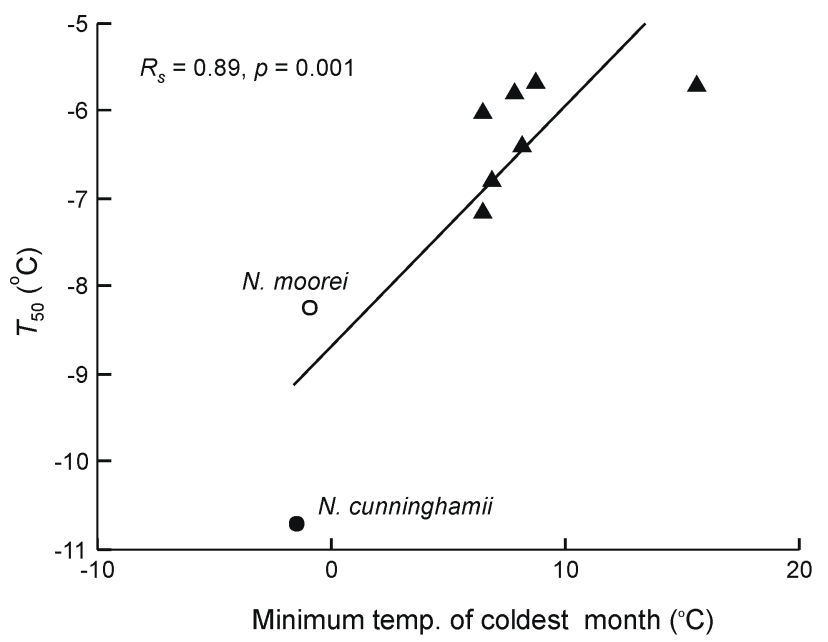

Figure 3. The relationship between frost resistance ( $T_{50^{\prime}}$ the temperature producing 50\% damage) and the minimum temperature of the coldest month (5-percentile values of species profiles) across evergreen Nothofagus species from New Guinea and Australia (updated from Read and Hope 1989). Climate data were estimated by BIOCLIM (Nix 1986), updated from Read et al. (2005). Tropical species are indicated by triangles, temperate species by circles. The result of Spearman correlation is given, using average $T_{50}$ values for species sampled from multiple populations (N. pullei, N. moorei and N. cunninghamii)

Like some of the New Guinea species, $N$. cunninghamii has a higher frost resistance than expected from the relationship with estimated MTCM values, relative to N. moorei (Figure 3). These suggested anomalies in frost resistance may reflect the importance of key climate variables not derived by the climate estimation model, including annual minima, number of frost days, or rare (e.g. decadal) severe frost events. However, they may also reflect the retention of traits resulting from greater exposure to colder conditions during the Pleistocene glacial periods in N. cunninghamii (Read and Hope 1989) and possibly some of the New Guinea species. Nothofagus was more common near the treeline in the late Pleistocene in New Guinea, in cooler (although possibly cloudier and so less exposed to frost) conditions (Walker and Hope 1982; Hope 2009). The particularly high frost resistance recorded in N. cunninghamii may reflect substantial increases in frost resistance that evolved during glacial periods, particularly if refugia were colder and drier than is currently experienced (McKenzie 1995, 2002; Worth et al. 2009), and might involve more complex genetic change. However, frost resistance is the 
outcome of a range of physiological and morphological traits (Larcher 2003, 2005), and these traits have multiple functions. For example, osmotic adjustment can contribute to resistance to both freezing and drought; tissues providing densely lignified or cutinized barriers (as in scleromorphic leaves of species such as $N$. cunninghamii) can potentially contribute to frost resistance (Larcher 2005) as well as drought resistance, and to protection from herbivores (Turner 1994) and possibly from damaging levels of light (Jordan et al. 2005). Hence, some leaf traits of $N$. cunninghamii may reflect efficient simultaneous resistance to the multiple stresses that prevail in seasonal cool temperate climates.

\section{Photosynthesis and growth responses to temperature}

Little information is available about growth responses to temperature for tropical and temperate Nothofagus species. Leaf flushes in the New Guinea species can occur throughout the year (Ash 1982), consistent with the low seasonal temperature range experienced by the species, together with high year-round rainfall. In contrast, both photosynthesis and growth are constrained by low winter temperatures in the southern species, with flushes of shoot growth largely confined to spring, sometimes with a second flush in summer (Howard 1973; Lowman 1992). However, the temperate evergreen species have a high acclimatory capacity, at least for photosynthesis. Under experimental conditions, leaves developed at $20^{\circ} \mathrm{C}$ adjusted to changing growth temperatures so that they maintained $80 \%$ of their maximum rate of net photosynthesis over a span of $14-17^{\circ} \mathrm{C}$; the tropical species showed an acclimatory capacity of only $8-11^{\circ} \mathrm{C}$ (Read 1990). Notably, no difference was recorded between tropical and temperate evergreen species in the acclimation temperature at which the maximum rate of photosynthesis was reached (Figure 4). These trends are consistent with the occurrence of tropical Nothofagus species in a climate that experiences relatively little daily and seasonal variation in maximum temperatures, and the restriction of temperate species to climates with higher daily and seasonal variability in temperature, but with similar hottest-month maximum temperatures (on average) (Table 1). The trends are also consistent with the changes in distribution recorded from the mid-Miocene, with subgenus Brassospora declining in abundance in southern Australia as temperature seasonality increased.

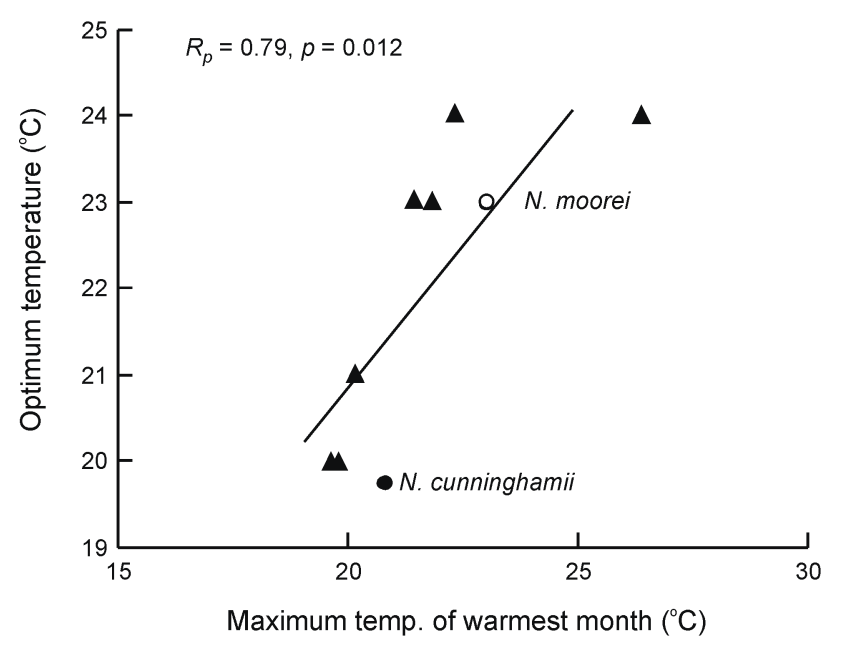

Similar trends have been recorded among other Australian rainforest species, with temperate species better able to maintain maximum rates of photosynthesis across a greater range of acclimation and growth temperatures than tropical species (Cunningham and Read 2002, 2003a), but with a lower optimum temperature for photosynthesis (Cunningham and Read 2002). Hence, the 'strategy' of the temperate species appears to be to produce a growth
Figure 4 . The relationship between the optimum acclimation temperature for photosynthesis and the maximum temperature of the warmest month (mean values of species profiles) across evergreen Nothofagus species from New Guinea and Australia (updated from Read and Hope 1996). Photosynthesis data were taken from Read (1990) and climate data were estimated by BIOCLIM (Nix 1986), updated from Read et al. (2005). Tropical species are indicated by triangles, temperate species by circles. The result of Pearson correlation is given, using average values of the optimum temperature for species sampled from cunninghamii) multiple populations ( $N$. pullei, $N$. moorei and $N$. 
flush in spring, the leaves then having a high capacity to adjust to the changing daily and seasonal temperatures, while the tropical species rely less on acclimation since they experience less variation in daily maxima across the year and potentially produce new leaves across a longer period (Read 1990; Cunningham and Read 2002, 2003a).

Whole-plant responses (e.g. carbon balance and growth rate) are likely to influence competitive success and contribute most to distributional changes. Little is known about comparative growth responses of tropical and temperate Nothofagus species to temperature. A study of some Australian tropical lowland rainforest trees showed higher temperature optima for growth than in temperate species, as expected from their occurrence in climates with higher mean annual maximum temperatures; however, the capacity to explain finer-scale latitudinal patterns of rainforest zonation based on growth responses was limited (Cunningham and Read 2003b). Much more research is needed in this area.

\section{Responses to water deficits}

In New Guinea, Nothofagus is typically associated with high rainfall and cloudiness in montane rainforests, where even the dry season seems to have relatively high and predictable rainfall (Ash 1982; Read et al. 2005). The responses of the New Guinea species to water deficits reflect this humid environment in which any water deficits are likely to be generally relatively short lived. Rates of leaf water loss tend to be low in the tropical Nothofagus species under experimental conditions of water deficit (Figure 5a), and higher long-term water-use efficiency has been recorded than in temperate species grown under common conditions (Read and Farquhar 1991), possibly due in part to higher stomatal sensitivity to water deficits. While this response seems paradoxical given the wet environment in which New Guinea species occur (and appears to contrast with some data from southern conifers: Brodribb and Hill 1998), stomatal sensitivity may be a relatively low-cost response to infrequent or short-lived water deficits. The main opportunity cost of foliar water conservation by reduced stomatal conductance is the potential reduction in photosynthetic rates. In ever-wet environments, this conservative response to water deficits may impose a relatively small opportunity cost. Nothofagus moorei, native to a summer-wet climate at mid-latitudes in Australia, shows a somewhat similar response (Figure 5a), but has better-developed mechanisms for enhancing water uptake than the New Guinea species (Read et al. 2010).

The very different response of $N$. cunninghamii, growing in southernmost Australia where the warmest time of the year is on average the driest (Table 1), indicates a more complex 'strategy'. Assimilation rates are limited in the cool-cold winters, so traits may be selected that maximise assimilation when temperatures are higher, in spring through to autumn. This may include mechanisms that enhance uptake of soil water, allowing high rates of stomatal conductance and thereby $\mathrm{CO}_{2}$ uptake and assimilation through drier periods. Nothofagus cunninghamii maintains higher rates of stomatal conductance, but develops low water potentials for a given decrease in tissue water content (Figure 5b) and a high root mass:leaf mass ratio (Read et al. 2010), traits that potentially enhance water supply to photosynthetic tissues. Hence, it seems to have a suite of traits that together should enhance assimilation and growth in a winter-dominated rainfall regime in which some degree of water deficit may be experienced in summer. However, such a strategy would limit growth in a summer-wet or ever-wet climate. That is, the water-spending habit when paired with costly diversion of resources to roots at the expense of leaves would probably only be competitively advantageous to plants occurring in climates in which photosynthesis is limited to a period that may experience dry conditions.

This difference in behaviour compared with $N$. moorei and the tropical species is consistent with the late appearance of $N$. cunninghamii (early Pleistocene, perhaps c. $1 \mathrm{Ma}$ ) (Jordan 1997) in the fossil record of southeast Australia. However, small-leafed forms of Nothofagus appear earlier in the fossil record, including during periods in which rainfall is likely to be high 
year-round (Hill 1983), and may reflect evolved responses to other environmental conditions. The traits shown by $N$. cunninghamii would be particularly advantageous when conditions deteriorated in the Neogene, with temperatures becoming more seasonal and rainfall decreasing (potentially with higher evaporative loads in summer), with the later development of a winterhigh rainfall regime.

(a)

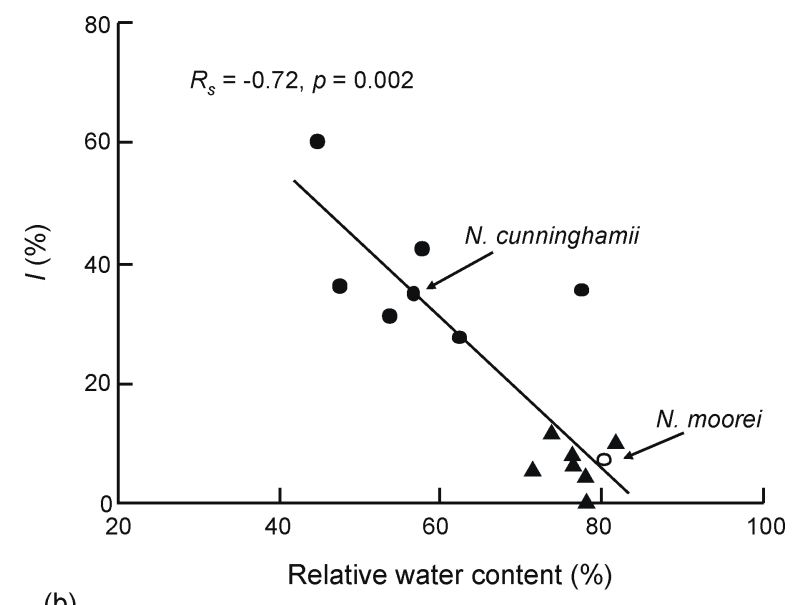

(b)

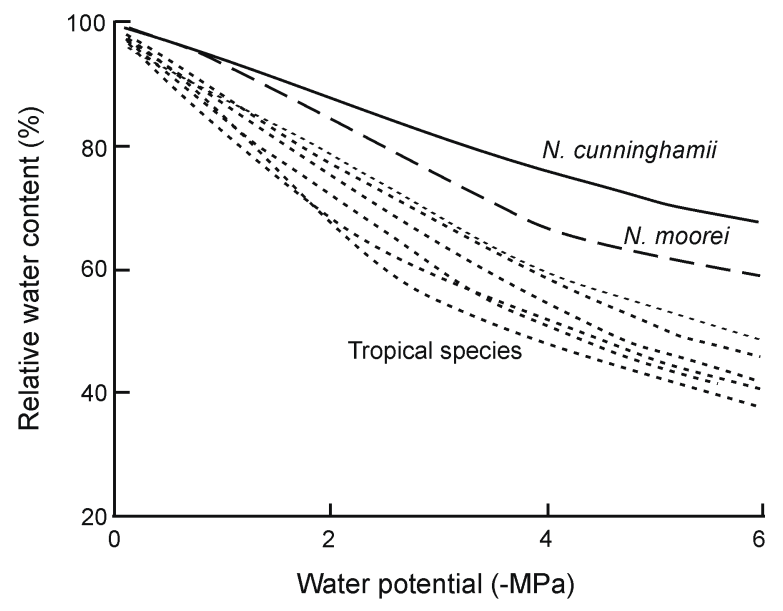

Figure 5. Comparisons of water relations traits between tropical and temperate evergreen Nothofagus species. (a) The relationship between leaf tissue damage (I, index of injury, calculated from leaching of solutes in damaged tissues) and relative water content in Nothofagus leaves $2 \mathrm{~h}$ after detachment (after Read et al. 2010). Tropical species and $N$. moorei maintain high water content and suffer little injury. Tropical species, triangles; temperate evergreen species from Australia, New Zealand and South America, circles. (b) The relationship between leaf relative water content and shoot water potential in detached leaves of evergreen species from New Guinea and Australia (from data in Read et al. 2010)

\section{Discussion}

There is still much to be learned in relation to distributional changes of key taxa such as Nothofagus, and the factors eliciting these changes and contributing to the evolution of the traits that today distinguish the temperate and tropical taxa. We note that other rainforest taxa, by having other ancestral traits and different phylogenetic constraints, may have been influenced by environmental changes in different ways from Nothofagus. In addition, species adapted to warmer conditions (e.g. tropical lowlands) or to different microenvironments, such as the rainforest understorey or lower canopy, may differ in a broad range of traits from Nothofagus species, which today typically dominate the uppermost canopy of montane or temperate lowland forests. Hence, the history and comparative biology of Nothofagus taxa may illustrate only part of the ecological history of rainforest in the region.

For Nothofagus, the palaeoecological history of this period appears to be as follows. During the wet and mild Palaeocene and warmer early Eocene, Nothofagus may have been present only in localised highland areas (Truswell 1993; McGowran et al. 2000). This is consistent with the current occurrence of evergreen Nothofagus in generally cool to mild conditions, even in the tropics (Read et al. 2005), with relatively low photosynthetic temperature optima 
(Read 1990). Given the ever-wet conditions thought to occur at this time, upland areas of even low elevation may have been exposed to frequent cloud-lie, as commonly experienced in New Guinea, and often associated with suboptimal conditions for plant growth (Grubb 1977; Read et al. 2005). In New Guinea, Nothofagus typically extends to lower altitudes (c. 600-1200 m asl) only on suboptimal sites, although current distribution patterns are likely to be moderated by the highly diverse flora of this region, particularly in the warmer lowland climates (Read et al. 2005). It is possible that 'megathermal' Nothofagus species existed in the Palaeogene that were lost in later cooling episodes, but there is little evidence to date. It is not clear to what extent declining $\mathrm{CO}_{2}$ levels contributed to the increasing abundance of Nothofagus in the late Eocene and the loss of some megathermal taxa.

Conditions were still cool in the Oligocene (but with more intense climatic gradients and so more variation in vegetation: McGowran et al. 2000) when Nothofagus diversity, including subgenus Brassospora, appeared to reach its maximum. At this time, 'tropical' (subgenus Brassospora) and 'temperate' (other subgenera) species were commonly contemporaneous, even within single fossil deposits (Hill 2001). There may have been some altitudinal separation of species, with subgenus Brassospora growing at lower elevations (Specht 1981), but macrofossil evidence suggests that diverse Nothofagus taxa coexisted at a finer scale (Hill 2001). This may have been possible because of the extremely wet and mild climate of the time, allowing coexistence of groups that may not be able to coexist in current climate regimes of this region (Hill 2001). Differential changes in distribution since that time suggest that differentiation in ecophysiology (and possibly in responses to disturbance) occurred among these groups of species. If that is the case, habitat segregation may have allowed landscape-level (or finerscale) coexistence - for example, with 'tropical' taxa occurring in habitats that experienced less variability and extremes of climate than 'temperate' taxa (Read et al. 1990a; Hill 2001).

By the early-middle Miocene, Nothofagus was less abundant in inland than coastal regions (Kershaw et al. 1994), and by the late Miocene to Pliocene, rainforest had declined in abundance across Australia and subgenus Brassospora had generally declined in abundance relative to subgenus Lophozonia (McGowran et al. 2000). The apparent decrease in suitable habitat, together with the decrease in the extent of rainforest per se (given that rainforest provides ameliorated microenvironments), is likely to have reduced refugial opportunities in both extent and environmental heterogeneity. Hence, there is likely to have been reduced capacity for effective plant migration through periods of environmental change, particularly for rainforest species that were more sensitive to changing conditions and/or had less-dispersible seeds - i.e. loss of some species may have been caused more by failure to keep pace with environmental change, than to regional loss of suitable environments. The reduction in the extent of rainforest is likely to have been strongly related to the decrease in annual precipitation (e.g. Brodribb and Hill 1998). However, conditions were also becoming cooler, with increased seasonality of both temperature and rainfall. Moreover, during the Plio-Pleistocene, there was a shift to winter-high rainfall in southeast Australia (Bowler 1982; Macphail et al. 1995). Hence, the contraction in rainforest may have been influenced by a broader suite of factors that influenced growth, reproduction and survival of the component species. By contrast, the Pliocene saw an expansion in montane habitat for Nothofagus in New Guinea and it expanded to maximum extent during glaciations in the Pleistocene (Hope 1996).

The apparent loss of diversity of Nothofagus in southeast Australia by the mid-ate Miocene, and the differential changes in distribution shown by the various taxa, were probably strongly influenced by cumulative effects of declining rainfall and temperature combined with increasing seasonality of both temperature and rainfall. Many of these species appear to have been lost from southern Australia before the severe deterioration associated with the glaciations of the late Neogene, judging from the reduced diversity of some Miocene fossil deposits, but timing of losses is very uncertain. In particular, the pairing of a seasonal temperature regime with drying summers may have contributed most to the loss of some evergreen Nothofagus 
taxa and the evolution of $N$. cunninghamii. The later shift to a winter-high rainfall regime would further contribute to the seasonal contrasts in conditions. To be successful in the altered climate regime of the southern rainforests, it appears to have been important (based on the biology of extant species) to optimise photosynthesis towards the growing season, part of which (summer) became drier than in the past. This could be achieved by (a) a high acclimatory capacity of photosynthesis, allowing high rates of photosynthesis through the wetter but cooler parts of spring and autumn, plus (b) strategies that enhance water uptake so that photosynthesis is not heavily limited during the warmer but drier months. These are the characteristics of $N$. cunninghamii, whose leaf type does not appear until relatively late in the fossil record (Jordan 1997), or at least is infrequent until that time. Nothofagus moorei, which also has the high acclimatory capacity of photosynthesis in relation to temperature of $N$. cunninghamii, appears to have higher stomatal sensitivity than its southern relative, consistent with the warmest time of the year being wet through its current range. This strategy reduces the requirement for alternative and less appropriate (in this climate) expenditure on means of increasing water uptake, e.g. increased allocation to root biomass, and is consistent with the loss of large-leafed species similar to $N$. moorei from southernmost Australia during the period when summers were becoming drier. That is, a $N$. moorei-like species may have had sufficiently broad temperature tolerance to persist for longer in the cooler and more seasonal climate, but would be predicted to have reduced growth rates (leading to reduced competitive ability) in climates with drier summers. It would be predicted to survive longest in climates with wetter summers, such as western Tasmania, and in oceanic rather than continental climates.

The climate deterioration in southeast Australia would particularly constrain growth and competitiveness of fossil species of subgenus Brassospora, if similar in biology to their extant relatives. Climatic deterioration may have at first just restricted species to wetter sites, since rainfall seasonality per se is not the problem, just its potential consequence of low-rainfall periods, particularly when these are associated with the summer of a seasonal temperature regime. This is consistent with the apparent loss of subgenus Brassospora and some other taxa with tropical affinities from all but the wettest areas during the Pliocene (Macphail et al. 1995; McGowran et al. 2000). At the same time, a drying climate before the switch to winter-high rainfall may have exacerbated the effects of climatic cooling and increased the likelihood of frosts. Some species of subgenus Brassospora may have persisted in southeast Australia longer than others, depending on differences in sensitivities to particular environmental factors. The loss of subgenus Brassospora from the wet highlands of northeast Australia during the Plio-Pleistocene (Kershaw and Sluiter 1982) might also have been influenced by increasing temperature seasonality and drier conditions, in addition to constraints imposed by the reduced areal extent of rainforest in response to drier conditions (Kershaw and Sluiter 1982).

It is not clear what limited the evolution of traits that enhanced tolerance of seasonality in the Brassospora group. A better knowledge of the biology of the New Caledonian Nothofagus species may help in this regard, since they occur in a more seasonal climate. At this stage, we can only note that evolution of tolerance of this climate regime in $N$. cunninghamii appears to have involved a coordinated suite of traits (even just for tolerance of summer-low rainfall), and that if its ancestor was more ecophysiologically similar to $N$. moorei, it was probably pre-adapted by some traits to the onset of the more severe conditions of the PlioPleistocene. A $N$. moorei-like ancestor has been suggested previously for $N$. cunninghamii (Hill 2001), but recent molecular evidence (Worth et al. 2009) casts some doubt on this hypothesis. There is also some recent evidence from fossil beetle remains that high annual rainfall and a summer-high rainfall climate persisted until c. $1.5 \mathrm{Ma}$ in southern Australia (Sniderman et al. 2009). This suggests a lesser role for the switch to winter-high rainfall for those rainforest taxa that had already declined in abundance in the region, and may provide further evidence of multiple and interacting factors in the loss of taxa that are restricted today 
to low latitudes, with probable variation among species in their sensitivity and responses to particular environmental changes.

One final trait of note in N. cunninghamii is its phenotypic variability, with considerable variation in leaf form and some physiological traits across its range. Data from juveniles grown in common environments suggest considerable genetic variation among populations in traits ranging from leaf form (Hovenden and Vander Schoor 2004) to ecophysiology (Read 1990; Hovenden and Brodribb 2000), possibly enhanced by the suggested multiple glacial refugia occupied during the Pleistocene (Worth et al. 2009). Genetic variability may be a key to the success of this species, and possibly of other geographically widespread species of Nothofagus (e.g. Premoli 1997). This, with the apparently superior acclimatory capacity of $N$. cunninghamii, may have engendered a greater vagility than some of its congeners, allowing it and its ancestors to keep pace with the climatic fluctuations (environmental 'steps and reversals': McGowran et al. 2000) seen through the Cenozoic in southeast Australia.

\section{Concluding remarks}

Study of living relatives of fossil Nothofagus species shows the potential responsiveness of vegetation and its component species to changes in seasonality, or at least to changes in seasonal conditions. Interpretation of climate based on nearest living relatives needs to take this into account - i.e. that species occurrence may reflect seasonal conditions and variability or even periodic extremes more than mean annual conditions. However, it is unclear to what degree the comparative biology of living species of Nothofagus indicates general mechanisms of change in diversity and species distributions in the history of southern rainforests. We also note the potential difficulty in unravelling effects of different features of the changing environment on species distribution, especially since environmental factors (e.g. climate, $\mathrm{CO}_{2}$ levels, soil and disturbance regimes) can influence species survival by both cumulative and interactive effects on plants that affect their competitiveness. One aspect not explored here is the contribution of changing climates to potentially complex changes in vegetation through factors such as altered fire regimes.

It is also becoming apparent that the recent evolutionary history of some species may be more complex than previously has been understood. In particular, a study of haplotype diversity suggests nesting of a $N$. moorei haplotype within the $N$. cunninghamii lineage (Worth et al. 2009), and so a more intricate and dynamic history than previously imagined. Clearly, further investigations of the fossil record, phylogenetic relationships and the biology of nearest living relatives are needed to assist in unravelling the history of past responses to environmental change in order to better understand vegetation responses of the future.

\section{Acknowledgements}

The great contribution by Geoff Hope to the vegetation history and ecology of the region is warmly acknowledged by his co-authors. We have been inspired variously by his skill, insights, dedication and enthusiasm as a teacher, research colleague, field guide and friend. 


\section{References}

Ash, J. 1982. The Nothofagus Blume (Fagaceae) of New Guinea. In J.L. Gressitt (ed.), Biogeography and ecology of New Guinea, Monographiae Biologicae Vol. 42 pp355-380. The Hague: Dr W. Junk Publishers.

Axelrod, D.I. 1984. An interpretation of Cretaceous and Tertiary biota in polar regions. Palaeogeography, Palaeoclimatology, Palaeoecology 45:105-147.

Bannister, P. 1976. Introduction to Physiological Plant Ecology. Oxford: Blackwell Scientific Publications.

Beerling, D.J. and C.K. Kelly 1996. Evolutionary comparative analyses of the relationship between leaf structure and function. New Phytologist 134:35-51.

Beerling, D.J., B.H. Lomax, D.L. Royer, G.R. Upchurch Jr and L.R. Kump 2002. An atmospheric $\mathrm{pCO}_{2}$ reconstruction across the Cretaceous-Tertiary boundary from leaf megafossils. Proceedings of the National Academy of Sciences 99:7836-7840.

Bowler, J.M. 1982. Aridity in the late Tertiary and Quaternary of Australia. In W.R. Barker and P.J.M. Greenslade (eds), Evolution of the flora and fauna of arid Australia, pp3545. Frewville, South Australia: Peacock Publications, in association with the Australian Systematic Botany Society and ANZAAS, South Australian Division, Inc.

Brodribb, T. and R.S. Hill 1998. The photosynthetic drought physiology of a diverse group of southern hemisphere conifer species is correlated with minimum seasonal rainfall. Functional Ecology 12:465-471.

Carpenter, R.J., G.J. Jordan and R.S. Hill 2007. A toothed Lauraceae leaf from the Early Eocene of Tasmania. International Journal of Plant Sciences 168:1191-1198.

Cunningham, S.C. and J. Read 2002. Comparison of temperate and tropical rainforest tree species: photosynthetic responses to growth temperature. Oecologia 133:112-119.

Cunningham, S.C. and J. Read 2003a. Do temperate trees have a greater capacity to acclimate to changing temperatures than tropical rainforest trees? New Phytologist 157:55-64.

Cunningham, S.C. and J. Read 2003b. Comparison of temperate and tropical rainforest tree species: Growth responses to temperature. Journal of Biogeography 30:143-153.

Donoso, C. 1996. Ecology of Nothofagus forests in Central Chile. In T.T. Veblen, R.S. Hill and J. Read (eds), The ecology and biogeography of Nothofagus forests, pp271-292. New Haven: University of Yale Press.

Givnish, T.J. 1979. On the adaptive significance of leaf form. In O.T. Solbrig, P.H. Raven, S. Jain and G.B. Johnson (eds), Topics in plant population biology, pp375-407. New York: Columbia University Press.

Givnish, T.J. 2002. Adaptive significance of evergreen vs. deciduous leaves: solving the triple paradox. Silva Fennica 36:703-743.

Grime, J.P. 1965. Comparative experiments as a key to the ecology of flowering plants. Ecology 46:513-515.

Grubb, P.J. 1977. Control of forest growth and distribution on wet tropical mountains: with special reference to mineral nutrition. Annual Review of Ecology and Systematics 8:83-107.

Hayes, P.A., J.E. Francis, D.J. Cantrill and J.A. Crame 2006. Palaeoclimate analysis of Late Cretaceous angiosperm leaf floras, James Ross Island, Antarctica. In J.E. Francis, D. Pirrie, and J.A. Crame (eds) Cretaceous-Tertiary high-latitude palaeoenvironments, James Ross Basin, Antarctica. Geological Society, London, Special Publications 258:49-62.

Hill, R.S. 1983. Evolution of Nothofagus cunninghamii and its relationship to N. moorei as inferred from Tasmanian macrofossils. Australian Journal of Botany 31:453-465.

Hill, R.S. 1991. Tertiary Nothofagus (Fagaceae) macrofossils from Tasmania and Antarctica and their bearing on the evolution of the genus. Botanical Journal of the Linnean Society 105:73-112. 
Hill, R.S. 1994. The history of selected Australian taxa. In R.S. Hill (ed.) History of the Australian Vegetation: Cretaceous to Recent, pp390-419. Cambridge: Cambridge University Press.

Hill, R.S. 2001. Biogeography, evolution and palaeoecology of Nothofagus (Nothofagaceae): the contribution of the fossil record. Australian Journal of Botany 49:321-332.

Hill, R.S. and M.E. Dettmann 1996. Origin and diversification of the genus Nothofagus. In T.T. Veblen, R.S. Hill and J. Read (eds) The ecology and biogeography of Nothofagus forests, pp11-24. New Haven: University of Yale Press.

Hill, R.S. and J. Read 1991. A revised infrageneric classification of Nothofagus (Fagaceae). Botanical Journal of the Linnean Society 105:37-72.

Hill, R.S. and L.J. Scriven 1997. Palaeoclimate across an altitudinal gradient in the OligoceneMiocene of northern Tasmania: an investigation of nearest living relative analysis. Australian Journal of Botany 45:493-505.

Hope, G.S. 1996. History of Nothofagus in New Guinea and New Caledonia. In T.T. Veblen, R.S. Hill and J. Read (eds) The ecology and biogeography of Nothofagus forests, pp257-270. New Haven: University of Yale Press.

Hope, G. 2009. Environmental change and fire in the Owen Stanley Ranges, Papua New Guinea. Quaternary Science Reviews 28:2261-2276.

Hovenden, M.J. and T. Brodribb 2000. Altitude of origin influences stomatal conductance and therefore maximum assimilation rate in Southern Beech, Nothofagus cunninghamii. Australian Journal of Plant Physiology 27:451-456.

Hovenden, M.J. and J.K. Vander Schoor 2004. Nature vs nurture in the leaf morphology of Southern beech, Nothofagus cunninghamii (Nothofagaceae). New Phytologist 161:585-594.

Howard, T.M. 1973. Studies in the ecology of Nothofagus cunninghamii Oerst. II. Phenology. Australian Journal of Botany 21:79-92.

Jordan, G.J. 1997. Evidence of Pleistocene plant extinction and diversity from Regatta Point, western Tasmania, Australia. Botanical Journal of the Linnean Society 123:45-71.

Jordan, G.J. and R.S. Hill. 1999. The phylogenetic affinities of Nothofagus (Nothofagaceae) leaf fossils based on combined molecular and morphological data. International Journal of Plant Sciences 160:1177-1188.

Jordan, G.J., R.A. Dillon and P.H. Weston 2005. Solar radiation as a factor in the evolution of scleromorphic leaf anatomy in Proteaceae. American Journal of Botany 92:789-796.

Kershaw, A.P. and I.R. Sluiter 1982. Late Cenozoic pollen spectra from the Atherton Tableland, north-eastern Australia. Australian Journal of Botany 30:279-295.

Kershaw, A.P., J.S. Clark, A.M. Gill and D.M. D'Costa 2002. A history of fire in Australia. In R.A. Bradstock, J.E. Williams and M.A. Gill (eds) Flammable Australia: the fire regimes and biodiversity of a continent, pp3-25. Cambridge: Cambridge University Press.

Kershaw, A.P., H.A. Martin and J.R.C. McEwan Mason 1994. The Neogene: a period of transition. In R.S. Hill (ed.), History of the Australian vegetation: Cretaceous to recent, pp299-327. Cambridge: Cambridge University Press.

Larcher, W. 2003. Physiological plant ecology: ecophysiology and stress physiology of functional groups. 4th ed. New York: Springer.

Larcher, W. 2005. Climatic constraints drive the evolution of low temperature resistance in woody plants. Journal of Agricultural Meteorology 61:189-202.

Lowman, M.D. 1992. Leaf growth dynamics and herbivory in five species of Australian rainforest canopy trees. Journal of Ecology 80:433-447.

Macphail, M.K., E.A. Colhoun and S.J. Fitzsimons 1995. Key periods in the evolution of the Cenozoic vegetation and flora in western Tasmania: the Late Pliocene. Australian Journal of Botany 43:505-526.

McElwain, J.C. and W.G. Chaloner 1996. The fossil cuticle as a skeletal record of environmental change. Palaios 11:376-388. 
McGowran, B., M. Archer, P. Bock, T.A. Darragh, H. Godthelp, S. Hageman, S.J. Hand, R. Hill, Q. Li, P.A. Maxwell, K.J. McNamara, M. Macphail, D. Mildenhall, A.D. Partridge, J. Richardson, S. Shafik, E.M. Truswell and M. Warne 2000. Australasian palaeobiogeography: the Palaeogene and Neogene record. Memoir of the Association of Australasian Palaeontologists 23:405-470.

McKenzie, G.M. 1995. Shifting patterns of Nothofagus cunninghamii (Hook.) Oerst rainforest in the late Quaternary of southeastern Australia: evidence from pollen. Historical Biology 9:257-268.

McKenzie, G.M. 2002. The late Quaternary vegetation history of the south-central highlands of Victoria, Australia. II. Sites below 900 m. Austral Ecology 27:32-54.

Nix, H.A. 1986. A biogeographic analysis of elapid snakes. In R. Longmore (ed.), Atlas of elapid snakes of Australia, pp4-15. Canberra: Australian Flora and Fauna Series No. 7, Australian Government Publishing Service.

Ogden, J., G.H. Stewart and R.B. Allan 1996. Ecology of New Zealand Nothofagus forests. In T.T. Veblen, R.S. Hill and J. Read (eds) The ecology and biogeography of Nothofagus forests, pp25-82. New Haven: University of Yale Press.

Otto-Bliesner, B.L. and G.R. Upchurch Jr 1997. Vegetation-induced warming of high-latitude regions during the Cretaceous period. Nature 385:804-807.

Pagani, M., J.C. Zachos, K.H. Freeman, B. Tipple and S. Bohaty 2005. Marked decline in atmospheric carbon dioxide concentrations during the Paleogene. Science 309:600-603.

Poole, I. and D.J. Cantrill 2006. Cretaceous and Cenozoic vegetation of Antarctica integrating the fossil wood record. In J.E. Francis, D. Pirrie, and J.A. Crame (eds) Cretaceous-Tertiary high-latitude palaeoenvironments, James Ross Basin, Antarctica. Geological Society, London, Special Publications 258:63-81.

Pole, M.S. and M.K. Macphail 1996. Eocene Nypa from Regatta Point, Tasmania. Review of Palaeobotany and Palynology 92:55-67.

Premoli, A.C. 1997. Genetic variation in a geographically restricted and two widespread species of South American Nothofagus. Journal of Biogeography 24:883-892.

Read, J. 1990. Some effects of acclimation temperature on net photosynthesis in some tropical and extra-tropical Australasian Nothofagus species. Journal of Ecology 78:100-112.

Read, J. and M.J. Brown 1996. Ecology of Australian Nothofagus forests. In T.T. Veblen, R.S. Hill and J. Read (eds) The ecology and biogeography of Nothofagus forests, pp131-181. New Haven: University of Yale Press.

Read, J. and G. Farquhar 1991. Comparative studies in Nothofagus (Fagaceae). I. Leaf carbon isotope discrimination. Functional Ecology 5:684-695.

Read, J. and J.E. Francis 1992. Responses of some Southern Hemisphere tree species to a prolonged dark period and their phytogeographic and palaeoecological implications for high-latitude Cretaceous and Tertiary floras. Palaeogeography, Palaeoclimatology, Palaeoecology 99:271-290.

Read, J. and R.S. Hill 1989. The response of some Australian temperate rainforest tree species to freezing temperatures and its biogeographical significance. Journal of Biogeography 16:21-27.

Read, J., R.S. Hill and G.S. Hope 2010. Contrasting responses to water deficits of Nothofagus species from tropical New Guinea and southern temperate forests: can rainfall regimes constrain latitudinal range? Journal of Biogeography.

Read, J. and G.S. Hope 1989. Foliar frost resistance of some evergreen tropical and extratropical Australasian Nothofagus species. Australian Journal of Botany 37:361-373.

Read, J. and G.S. Hope 1996. Ecology of Nothofagus forests of New Guinea and New Caledonia. In T.T. Veblen, R.S. Hill and J. Read (eds) The ecology and biogeography of Nothofagus forests, pp200-256. New Haven: University of Yale Press. 
Read, J., G.S. Hope and R.S. Hill 1990a. Integrating historical and ecophysiological studies in Nothofagus to examine the factors shaping the development of cool rainforest in southeastern Australia. In J.G. Douglas and D.C. Christophel (eds) Proceedings of the 3rd International Organisation of Palaeobotany Symposium, 1988. pp97-106.

Read, J., G.S. Hope and R.S. Hill 1990b. The dynamics of some Nothofagus-dominated rainforests in Papua New Guinea. Journal of Biogeography 17:185-204.

Read, J., G.S. Hope and R.S. Hill 2005. Phytogeography and climate analysis of Nothofagus subgenus Brassospora in New Guinea and New Caledonia. Australian Journal of Botany 53:297-312.

Royer D.L., C.P. Osborne and D.J. Beerling 2003. Carbon loss by deciduous trees in a $\mathrm{CO}_{2}-$ rich ancient polar environment. Nature 424:60-62.

Royer, D.L. and P. Wilf 2006. Why do toothed leaves correlate with cold climates? Gas exchange at leaf margins provides new insights into a classic paleotemperature proxy. International Journal of Plant Sciences 167:11-18.

Sauquet, H., P.H. Weston, C.L. Anderson, N.P. Barker, D.J. Cantrill, A.R. Mast and V. Savolainen 2009. Contrasted patterns of hyperdiversification in Mediterranean hotspots. Proceedings of the National Academy of Sciences 106:221-225.

Scriven, L.J., S. McLoughlin and R.S. Hill 1995. Nothofagus plicata (Nothofagaceae), a new deciduous Eocene macrofossil species, from southern continental Australia. Review of Palaeobotany and Palynology 86:199-209.

Sniderman, J.M.K., N. Porch and A.P. Kershaw 2009. Quantitative reconstruction of Early Pleistocene climate in south-eastern Australia and implications for atmospheric circulation. Quaternary Science Reviews 28:3185-3196.

Specht, R.L. 1981. Evolution of the Australian flora: some generalizations. In A. Keast (ed.) Ecological Biogeography of Australia, pp783-805. The Hague: Dr W Junk Publishers.

Specht, R.L., M.E. Dettmann and D.M. Jarzen 1992. Community associations and structure in the Late Cretaceous vegetation of southeast Australasia and Antarctica. Palaeogeography, Palaeoclimatology and Palaeoecology 94:283-309.

Spicer, R.A. 1987. The significance of the Cretaceous flora of northern Alaska for the reconstruction of the climate of the Cretaceous. Geologisches Jahrbuch A 96:265-291.

Turner, I.M. 1994. Sclerophylly: primarily protective? Functional Ecology 8:669-675.

Truswell, E.M. 1993. Vegetation changes in the Australian Tertiary in response to climatic and phytogeographic forcing factors. Australian Systematic Botany 6:533-557.

Van Steenis, C.G.G.J. 1971. Nothofagus, key genus of plant geography, in time and space, living and fossil, ecology and phylogeny. Blumea 19:5-98.

Veblen, T.T., C. Donoso, T. Kitzberger and A.J. Rebertus 1996. Ecology of southern Chilean and Argentinean Nothofagus forests. In T.T. Veblen, R.S. Hill and J. Read (eds) The ecology and biogeography of Nothofagus forests, pp293-353. New Haven: University of Yale Press.

Walker, D. and G.S. Hope 1982. Late Quaternary vegetation history. In J.L. Gressitt (ed.) Biogeography and ecology of New Guinea, pp263-285. The Hague: Dr W. Junk Publishers.

Wilf, P., S.L. Wing, D.R Greenwood and C.L. Greenwood 1998. Using fossil leaves as paleoprecipitation indicators: An Eocene example. Geology 26:203-206.

Woodward, F.I. 1987. Climate and plant distribution. Cambridge: Cambridge University Press.

Worth, J.R.P., G.J. Jordan, G.E. McKinnon and R.E. Vaillancourt 2009. The major Australian cool temperate rainforest tree Nothofagus cunninghamii withstood Pleistocene glacial aridity within multiple regions: evidence from the chloroplast. New Phytologist 182:519-532. 